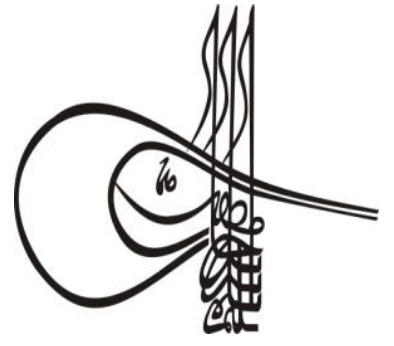

Received/Geliș: 20.06.2019

\section{Tutkigh Studies \\ Social Sciences}

Volume 14 Issue 4, 2019, p. 1601-1614

DOI: 10.29228/TurkishStudies.23330

ISSN: 2667-5617

Skopje/MACEDONIA-Ankara/TURKEY

Research Article / Araştırma Makalesi

Article Info/Makale Bilgisi

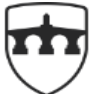

INTERNATIONAL BALKAN UNIVERSITY

EXCELLENCE FOR THE FUTURE IBU.EDU.MK

ar Report Dates/Rapor Tarihleri: Referee 1 (15.07.2019)-Referee 2 (26.07.2019)

This article was checked by intihal.net.

\title{
YAŞAMDA ANLAM VARLIĞININ ÖRGÜTSEL PSİKOLOJİK SERMAYE İLE İLIŞKİSi
}

\author{
Cengiz $A \breve{G}^{*}$ - Oktay $B A L C I^{* *}$
}

\begin{abstract}
ÖZ
Pozitif psikoloji yönetim alanında geniş yankı uyandırmıştır. "Yaşamın anlamı" kavramı pozitif psikolojinin yönetim alanına kazandırdığı önemli kavramlardan biridir. Araştırmalar yaşamında anlam bulan kișilerin fiziksel ve ruhsal açıdan daha sağlıklı olduğunu göstermektedir. Yönetim disiplini açısından bunun anlamı daha enerjik ve daha mutlu çalışan demektir. Benzer şekilde "psikolojik sermaye" de pozitif psikolojinin örgütler üzerindeki pozitif yansımasından ibaret olan diğer bir kavramdır. Bu bağlamda araştırmamızın başlangıç noktası "Yaşamını anlamlı gören bireyin bu kazanımı acaba onun öz yeterlik / umut / iyimserlik / psikolojik dayanıklılık gibi durumlarına da etki etmektedir mi?" sorusu olmuştur.

$\mathrm{Bu}$ araștırmanın evrenini 2019 yılında İstanbul'da Avrupa yakasında toplu taşıma sektöründe görev yapan kişiler oluşturmaktadır. Araştırmanın örneklemini Esenler ve Bakırköy ilçesinde görev yapan kamu çalışanları oluşturmaktadır. Çalışanların "yaşam anlam varlığını" ölçmek için Steger, Frazier, Oishi ve Kaler (2006) tarafından geliştirilen ölçek kullanılmıştır. Çalışanların "Örgütsel Psikolojik Sermaye" algısını ölçmek amacıyla Luthans ve diğerleri (2007) tarafından geliştirilen Psikolojik Sermaye Ölçeği kullanılmıştır. Yapılan korelasyon ve regresyon analizinden sonra çalışanların yaşamda anlam varlığı algısı ile örgütsel psikolojik sermayenin dört boyutu (öz yeterlilik, umut, iyimserlik, dayanıklı1ık) arasında pozitif yönde ilişki tespit edilmiştir. Böylece bireyin yaşamda anlam varlığının, örgütsel psikolojik sermaye kavramının tüm boyutlarını pozitif yönde etkilediği ortaya koyulmuştur.
\end{abstract}

Dr. Öğr. Üyesi, Nişantaşı Üniversitesi, E-posta: cengizag@gmail.com

Dr. MEB, E-posta: oktaybalci@gmail.com 
Anahtar Kelimeler: Yaşamda anlam varlığı, psikolojik sermaye, öz yeterlilik, umut, iyimserlik, psikolojik dayanıkl1lık

\title{
THE RELATIONSHIP BETWEEN PRESENCE OF MEANING IN LIFE AND ORGANIZATIONAL PSYCHOLOGICAL CAPITAL
}

\begin{abstract}
"Meaning in life" is one of the most important concept in management acquired from positive psychology. Studies have shown that individuals who found meaning in life are better in terms of mental and physical health. This means for management discipline that having happier and more energetic personnel. In a similar vein psychological capital is another important concept in management acquired from positive psychologhy. In this context we wonder if a personel who have presence of meaning in life, does it help to enhance their self-efficiacy, hope, optimism and resilience states of psychological capital. This question is the inception point of the study.

The universe of this study are personnels working in public transport sector in İstanbul European Side, in 2019. The sample of this study are public transportation personnels working in Esenler and Bakırköy. In order to collect data "organizational psychological capital" (Luthans, F., Bruce A., Avey, J. B. \& Norman, S. M,2007) and "meaning in life questionnaire" (Steger, Frazier, Oishi and Kaler ,2006) scales were used. The results of regression and correlation analyses showed that there is a positive and meaningful relationship between the dimension of meaning in life namely "presence of meaning in life" and four dimensions (hope, resilience, optimism, self-efficiacy) of psychological capital. Thus we found out that the presence of meaning in life effects positively all dimensions of psychological capital.
\end{abstract}

\section{STRUCTURED ABSTRACT}

Questions such as "What is the meaning of life" are of the most ancient ones in human history. Individuals usually look for a spiritual or a metaphysical meaning not only for themselves but to explain the existence of all of the living and the inanimate beings. This search for meaning is called cosmic meaning. Nevertheless, "what is the meaning of my life? " is the the question addresses the individual and expresses nature of the meaning for the individual's own life. Therefore, the search for meaning in this direction is called "terrestrial meaning" (Yalom, 1980: 423).

The presence of the meaning in life expresses the importance, meaning and value attributed to the existence of the individual. The search for meaning in life is the effort to find or deepen the meaning of an individual's existence. Meaning in life includes both the presence of meaning and the search for meaning. The person seeking meaning may not have found it yet. One who believes to find meaning, may continue to seek to deepen or enrich the meaning (Steger et al., 2006: 85). 
Positive psychology has recently begun to show its strong influence on science for management. Positive psychology has three pillars. First, positive psychology deals with positive emotions. Second, positive psychology emphasizes the positive qualities of people, such as strength and virtue. Third, positive psychology deals with positive institutions managed by positive emotions (Seligman, 2002: xi). The concept of psychological capital has emerged as a natural result of positive psychology. There are four components of psychological capital. These; optimism, hope, resilience and self-sufficiency.

Optimism means that individuals believe that they will be successful now and in the future, and that good things will happen to them (Luthans et al., 2007: 542). According to Seligman (2006: 71), optimism can be learned, and he also claimed that the individual can improve the quality of life through optimism.

Hope means to resist until the end to reach the goal and to keep the belief that success will always be fresh (Luthans et al., 2007: 542). Synder et al. (2002: 257) argued that hope consists of two dimensions: the ability to seek, to achieve the goal, and the ability to find ways to achieve it. Highly hopeful people are willing to find alternative paths if the first path to the goal is obstructed (Synder et al., 2000: 749).

Resilience is meant to show tolerance and patience when faced with challenges and frustrations by individuals (Luthans et al., 2007: 542). Maddi (2006: 228) described psychological resilience as an individual's ability to reduce stress and respond to stressful events. Individuals with high psychological resilience have mature, responsible, optimistic, helpful, goal-oriented, curious and resistant personality traits (Eley et al., 2013: 15).

Self-efficacy means that individuals put forth the energy to cope with difficult tasks and problems, and trust their own abilities (Luthans et al., 2007: 542). Individuals with high self-efficacy are more prone to taking initiative and setting challenging goals (Flammer, 2001: 1).

In this research, it is aimed to determine the relationship between the meaning of life for the people working in public transport sector, and organizational psychological capital (self-efficacy, hope, optimism, resilience).

The universe of this study are of personnels working in public transport sector in İstanbul European Side, in 2019. The sample of this study are of public personnels working in Esenler and Bakırköy. In order to collect the data, the organizational psychological capital (Luthans, F., Bruce A., Avey, J. B. \& Norman, S. M,2007) and the "meaning in life questionnaire" (Steger, Frazier, Oishi and Kaler ,2006) scales were used.

The results of regression and correlation analyses showed that there is a positive and meaningful relationship between the dimension of meaning in life, namely "presence of meaning in life" and four dimensions (hope, resilience, optimism, self-efficiacy) of psychological capital. Thus we found out that the presence of meaning in life effects positively all dimensions of psychological capital.

In our research, a positive relationship was found between the presence of meaning in life, and the "self-efficacy" dimension of 
organizational psychological capital. The presence of meaning in life represents the degree to which an individual sees his or her life as important, meaningful and valuable. A positive relationship was found between the presence of meaning in life, and the optimism dimension of organizational psychological capital. According to the findings of the study, it is possible to say that individuals who find their lives meaningful can show an optimistic attitude that they will succeed now, and in the future. Hope represents that an individual does not lose hope on the path to the goal. In the light of the findings of the research, it is possible to say that individuals who find meaning in their lives are less likely to lose hope. It was found that there is a positive relationship between the presence of meaning in life, and the resilience dimension of organizational psychological capital. Resilience means to survive in the face of difficulties with respect to the matter. In this context, it was possible to say that individuals who find meaning in life can be of the more resistant to difficulties.

This research was carried out in order to emphasize the importance of the existence of meaning in life, and the components of organizational psychological capital together in the organizational behavior sciences, and to contribute to the studies of the researchers who will work on this subject. In reality, this kind of study is to be performed for the first time in Turkey, for that, such a study is of atmost importance.

Keywords: Presence of meaning in life, psychological capital, hope, resilience, optimism, self-efficacy

\section{Giriş}

\subsection{Yaşamın anlamı}

"Hayatın anlamı nedir?” veya "Yaşamımım anlamı nedir?” soruları şüphesiz insanlık tarihinin en kadim sorularıdır. "Hayatın anlamı nedir?” sorusu genel anlamda insan hayatının tümüyle tutarlı bir örüntüye sahip olup olmadığını sorgulamaktadır. Birey burada sadece kendini değil evrendeki tüm canlı ve cansız varlıkların varoluş nedeninde, ruhani veya metafizik bir neden aramaktadır. Bu anlam arayışına "kozmik anlam" adı verilmektedir. Oysa "Yaşamımım anlamı nedir?" sorusu bireyseldir ve bireyin kendi yaşamının anlamını sorgulamasını ifade etmektedir. Dolayısıyla bu yönde bir anlam arayışına “dünyevi anlam” adı verilmiştir (Yalom,1980:423). Adler'e (1985:8) göre insanlar genellikle "dünyevi anlam" sorusunu yenilgiye uğradıkları zaman sormaktadır. Zira Adler insanların "Yaşam tekneleri yelken açmış güzel güzel yol aldı̆̆ı zaman, çetin sınavlardan geçmeleri gerekmediği sürece insanlar böyle bir soruyu sözcüklere döküp açı̆̆a vurmayacaklarını’ileri sürmüştür. Fakat son zamanlardaki araştırmalar yaşamın anlam varlığının pozitif psikoloji (yaşam doyumu; Steger ve diğ., 2006), (iyi oluş; Doğan ve diğ., 2012) (Zika ve Chambrelin, 1992), (umut; Feldman ve Synder,2005), (mutluluk; Seligman ve Csikszentmihalyi, 2000) ve (kendini toparlama gücü; Wong ve Wong, 2012), (travma sonrası gelişim; Triplett ve diğ.,2012) kavramları ile yakından ilişkili olduğunu göstermektedir.

Yaşamda anlam varlığı, bireyin varoluşuna yüklediği önem, anlam ve değeri ifade etmektedir. Yaşamda anlam arayışı ise bireyin varoluşunun anlamını bulma veya derinleştirme çabasıdır. Dolayısıyla yaşamda anlam bireyin hem anlam varlığını hem de anlam arayışını içerebilmektedir. Anlam arayan birey henüz onu bulamamış olabilmekte, veyahut anlamı bulduğuna inanan biri, anlamı derinleştirmek veya zenginleştirmek için arayışa devam etmiş olabilmektedir (Steger ve dĭg.,2006:85). Baumeister ve Vohs'a göre (2005:610) bireyin anlam arayışını kavramak için dört temel ihtiyacın gözden geçirilmesi gerektiğini ileri sürmüştür. Bunlar (1) bireyin bir amaca sahip olma ihtiyacı (2) 
bireyin değerlere sahip olma ihtiyacı (3) bireyin öz yeterlilik ihtiyacı (4) bireyin öz saygı ihtiyacıdır. Martele ve Steger (2016:531) benzer şekilde yaşamın anlamının üç anlama geleceğini ileri sürmüştür. İlk anlam, bireyin yaşamını mantığa büründürme çabalarını ifade etmektedir (Uyum). İkincisi, bireyin yaşamına bir yön veya hedef belirlemesini sağlamasıdır (Amaç). Üçüncüsü ise bireyin yaşanmaya değer bir hayatı yaşadığını temsil etmektedir (Değer).

Modern psikoloji, kozmik anlamın metafizik boyutundan dolayı dünyevi anlam üzerinde yoğunlaşmıştır. Modern araştırmalar bireyin yaşamında anlamı yakalamasının ona mutluluk ve tatmin edici bir yaşam sunduğunu göstermektedir (Bannik,2017:151). Burada bahsedilen mutluluk hazc1 (hedonik) bir boyuttan ziyade işlevsel (eudaimonic) bir boyutu içermektedir (Seligman, 2002:260). Zira mutluluk bugüne yönelik değil, geçmiş, bugün ve gelecek ile ilgili bir kavramdır (Baumeister ve diğ., 2013:505). Öte yandan bireyin yaşamında anlamsızlık bir varoluşsal nevroz veya hastalık olarak tanımlamıştır. Anlamsızlık yaşayan birey duygusuz, empati yoksunu, amaçsız, eylemsiz ve can sıkıntısı yaşadığı öngörülmektedir (Maddi,1967:311).

Frankl (2012:125) bireylerin yaşamlarına ancak üç şekilde anlamlı kılacağını ileri sürmüştür. İlki bir eser veya bir iş yaparak yaşama anlam katma çabasıdır. İkincisi ise insanlarla sevgi odaklı bir etkileşim içinde olunarak yaşama anlam katılmasıdır. Kaçınılmaz acıya yönelik güçlü bir tavır geliştirmek ise yaşamda anlam oluşturmanın son yolu sayılmaktadır.

Yalom'a (1980:419-422) göre anlamsız ve amaçsız bir hayatta birey sıkıntılarla baş edememekte ve akıl sağlığı tehlikeye girmektedir. Bu yüzden birey içinde bulunduğu anlamsızlığa karş1 yaratıcı bir yanıt (creative response) vererek yaşamını anlamlandırmaya çalışmalıdır. Birey kendini bir şeye yürekten adayarak veya diğerkâmlık göstererek yaşamını anlamlandırabilir.

Adler'e (1985:9) göre her insanın kendini bekleyen üç temel ödeve karşı geliştirdiği çözüm onun yaşamın anlamından ne anladığını ortaya koyacaktır. Birincisi, içine doğduğumuz dünya denen gezegenin bizlere sunduğu sinırlılık ve olanaklar çerçevesinde her birey kendisini ruhsal ve bedensel bakımdan geliştirmek zorundadır. İkincisi, insanın dünyada tek başına değil, bir toplum içinde yaşadığı gerçeğidir. Zira bireyin tek başına hedeflerine ulaşması mümkün değildir. Bu yüzden birey diğer insanlarla el ele çalışarak hem kendi hem de insanlığın yaşamını sürdürme çabası içinde olmalıdır. Üçüncüsü ise bireyin sevgi ve evlilik ödevidir. Bireyin ve toplumun varlığını sürdürmesi için bu gereklidir.

Pyszcynski ve diğerleri (2015:4) yaşamın anlamını Terör (Dehşet) Yönetimi Teorisi ile açıklamaya çalışılmışlardır. Bu teori ölümün varlığı ve kaçınılmazlığı karşısında dehşet yaşayan bireyin içinde doğduğu toplumun kültürel dünya görüşünü benimseyerek bu dehşet ile baş etmesini ifade etmektedir.

\subsection{Psikolojik Sermaye}

Pozitif psikoloji güçlü etkisini son zamanlarda yönetim bilimi üzerinde de göstermeye başlamıştır. Pozitif psikolojinin üç temel ayağı vardır. Birincisi, pozitif psikoloji pozitif duygular ile ilgilenmektedir. İkincisi, pozitif psikoloji insanların güç ve erdem gibi pozitif özelliklerini öne çıkarmaktadır. Üçüncüsü, pozitif psikoloji pozitif duygularla ile yönetilen pozitif kurumlar ile ilgilenmektedir (Seligman, 2002: xi). Psikolojik sermaye kavramı ise pozitif psikolojinin doğal bir sonucu olarak ortaya çıkmıştır. Bu kavram günümüz rekabetçi küresel ekonomi içerisinde yerini almak isteyen bütün örgütler için bugün çok önemli bir kaldıraç rolündedir (Froman, 2010:62). Psikolojik sermaye insan kaynaklarının ölçülebilen, geliştirilebilen ve yönetilebilen pozitif yetenekleri üzerine yoğunlaşmakta ve "kim olduğumuz?" ve "ne kadar güçlü olduğumuz?" sorularıyla ilgilenmektedir (Luthans ve diğ., 2004:46). 
Psikolojik sermayenin dört bileşeni mevcuttur. Bunlar iyimserlik, umut, psikolojik dayanıklılık ve öz yeterliliktir. İyimserlik, bireyin şimdi ve gelecekte başarılı olacağına ve başına iyi şeyler geleceğine inanması demektir (Luthans ve diğ., 2007:542). Bir başka deyişle iyimserlik, kişilerin her sıkıntıda bir hayır olduğu düşüncesine sahip olmalarıdır. Seligman (2006:71) iyimserliğin öğrenilebileceğini ve bireyin yaşam kalitesini yükseltebileceğini iddia ermiştir. Seligman'a göre iyimser olmak bencil ve kendine aşırı güvenme demek değildir, aksine bireyin kendi kendiyle cesaretlendirici şbiçimde konuşabileceğini öğrenmesi demektir.

Umut, hedefe varmak için sonuna kadar direnmek ve başarıya ulaşacağına dair inancı her daim taze tutmak demektir (Luthans ve diğ., 2007:542). Synder ve diğerleri (2002:257) umudu, amaca ulaşmayı isteme ve amaca ulaşma yollarını bulabilme becerisini olmak üzere iki boyuttan oluştuğunu ileri sürmüştür. Yüksek düzeyde umutlu kişiler amaca giden ilk yolun tıkalı olması halinde alternatif yollar bulmaya teşnedirler (Synder ve diğ.,2000:749). Dolayısıyla yüksek düzeyde umutlu kişiler hedeflerine ulaşabilmek için hem irade gücüne hem de kendilerini o hedefe ulaştıracak alternatif yollara sahip olacaklarını söylemek mümkündür (Luthans ve diğ.,2007:63).

Psikolojik Dayanıklılık, bireyin zorluk ve sıkıntı ile karşılaştığında tahammül ve sabır göstermesi demektir (Luthans ve diğ., 2007:542). Maddi (2006:228) psikolojik dayanıklılı̆̆ bireyin stres veren olaylar karşısında stresi azaltabilme ve olaya müdahale etme becerisi olarak tarif etmiştir. Couto (2002) psikolojik dayanıklılığı bir hakikatle yüzleşme, hedeflere bağlılık ve anlam arama süreci olduğunu ve bireyin başarısında eğitim ve deneyimden daha etkili olabileceğini ileri sürmüştür. Psikolojik dayanıklılık (resilience) bazı kaynaklarda Türkçe'ye" kendini toparlama gücü" olarak da aktarılmıştır (Işık,2016:71). Nitekim "Resilience" sözcüğü kök olarak Latince "resilere"'sözcüğünden gelmektedir ve bu sözcüğün anlamı da "geriye sıçramak" olarak açıklanmaktadır. O halde psikolojik dayanıklılığı yüksek bireylerin stres veren olaylar veya hastalıklar karşısında kolayca ve çabukça iyileşebileceğini söylemek mümkündür. Psikolojik dayanıklılığı yüksek bireyler olgun, sorumlu, iyimser, yardımsever, amaç odaklı, meraklı ve dirençli kişilik özelliklere sahiptir (Eley ve diğ.,2013:15).

Öz yeterlilik, bireyin zorlu işler ve problemler ile baş edecek enerjiyi ortaya koyması ve kendi yeteneklerine güvenmesi demektir (Luthans ve diğ., 2007:542). Öz yeterlilik kavramının özünde bireyin "sanırım yapabilirim, başarabilirim" düşüncesi yatmaktadır. Öz yeterliliği yüksek bireyler inisiyatif almaya ve zorlu amaçlar belirlemeye daha çok yatkınlardır (Flammer,2001:1). Bandura'ya (1994:2) göre bireyin öz yeterliliği geliştirmesinde tam ve doğru deneyimlerin, dolaylı yaşantıların (rol model etkisi), sosyal iknanın, fiziksel ve duygusal durumların önemli rolü vardır. Öz yeterlilik büyüklük, güç ve genellenebilirlik olmak üzere üç boyuttan oluşmaktadır. Büyüklük boyutu bireyin bir işi yerine getirebileceğine dair inancı temsil etmektedir. Güç boyutu ise bireyin işi yerine getirebileceğine dair güvendir. Genellenebilirlik boyutu ise öz yeterliliğin bir durumdan başka durma değişebileceğini ifade etmektedir (Özerden,2010:12).

\section{Yöntem}

2.1. $\mathrm{Bu}$ araştırmada toplu taşıma sektöründe çalışan insanların yaşamdaki anlam ile örgütsel psikolojik sermaye (öz yeterlik, umut, iyimserlik, psikolojik dayanıklılık) arasındaki ilişki tespit edilmek istenmiştir. "Yaşamını anlamlı gören bireyin bu kazanımı acaba onun öz yeterlik /umut / iyimserlik / psikolojik dayanıklılık gibi durumlarını da etki etmektedir mi?" sorusu araştırmamızın başlangıç noktası olmuştur.

\subsection{Araştırmanın Değişkenleri ve Hipotezler}

Alan yazında yaşamda anlam varlığının pozitif duygular (yaşam doyumu, Steger ve diğ.,2006; mutluluk, Seligman ve Csikszenmihalyi,2000) ile yakından ilişkili olduğuna dair çalışmalar mevcuttur. Bu yüzden kavram pozitif psikoloji çatısı altında değerlendirilmiştir. 'Kim olduğum?" ve "Pozitif gelişim sayesinde ne olabilirim?" soruları ise psikolojik sermayeye ait sorularıdır ve bireyin örgüt 
içindeki pozitif psikolojik gelişim durumunu belirlemektedir (Luthans ve diğerlerine (2004). Bu soruları "yaşamın anlamı" kavramı çerçevesinde tekrar ele aldığımızda "yaşamda anlam varlığı" ve "yaşamda anlam arayışına" tekabül edebileceğini söylemek mümkündür. Nitekim tıpkı yaşamda anlam varlığı gibi pozitif psikolojik sermayenin de pozitif duygular (Avey ve diğ.,2008), psikolojik iyi oluş (Yaşin,2016) gibi kavramları pozitif yönde; stres (Avey ve diğ.,2009) ve tükenmişlik (Ocak ve Güler,2012) gibi kavramları ise negatif yönde etkilediği görülmüştür. Avey ve diğerleri (2010) yüksek psikolojik sermayeli bireylerin iş yerinde çabalarıyla fark yaratacaklarına, istikrarlı bir çalışan olduğunu, zorlu işleri sevdiğini ve stres veren olaylar karşısında sakin kaldıklarını ifade etmişlerdir.

Psikolojik sermaye, insan gelişimine ve performansın iyileştirilmesine yoğunlaşmaktadır. İnsanın kişisel özelliklerinden ziyade kişisel "durumlarını" öne çıkarmaktadır. Durumlar, duygu ve ruh hallerinden oluşmaktadır. Kişisel özellikler sabit ve değişime kapalı iken, durumlar gelip geçici olmakla birlikte değişime de açıktırlar (Cantore ve Passmore,2012). Bu değişim bireylerin pozitif olarak gelişimini ifade etmektedir. Yaşamda anlam varlığı ise bireyin yaşamını anlamlı hissetmesini ifade etmektedir. Bireyin hayatına etki eden bilişsel, duygusal ve davranışsal yönlerini kapsamaktadır. İdealize ettiği yaşam ile mevcut yaşamı arasındaki uyum bireyin yaşamında anlam varlığına işaret etmektedir (Taş,2015). Bu bağlamda araştırmanın modeli ve hipotezleri aşağıdaki gibi kurulmuştur.

\section{Bağımsız Değişken}

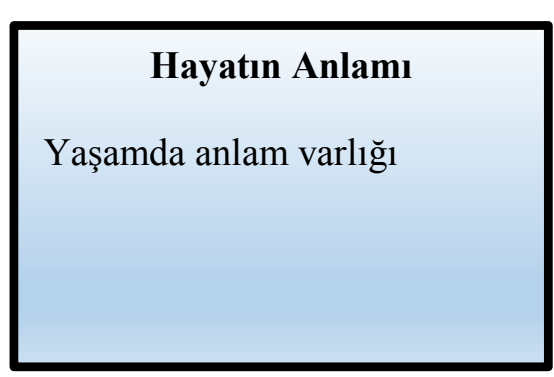

\section{Bağımlı Değişken}

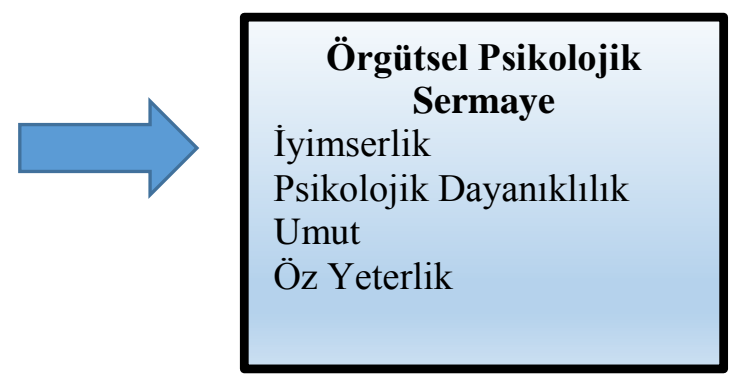

H1: Yaşamda anlam varlığı algısı ile örgütsel psikolojik sermayenin öz yeterlilik boyutu arasında pozitif yönde ilişki vardır

H2: Yaşamda anlam varlığı algısı ile örgütsel psikolojik sermayenin iyimserlik boyutu arasında pozitif yönde ilişki vardır.

H3: Yaşamda anlam varlığı algısı ile örgütsel psikolojik sermayenin umut boyutu arasında pozitif yönde ilişki vardır.

H4: Yaşamda anlam varlığı algısı ile örgütsel psikolojik sermayenin psikolojik dayanıklılık boyutu arasında pozitif yönde ilişki vardır.

\subsection{Araştırmanın evreni ve örneklemi}

Araştırmanın evrenini 2019 yılında İstanbul'da Avrupa yakasında toplu taşıma sektöründe görev yapan kişiler oluşturmaktadır. Araştırmanın örneklemini Esenler ve Bakırköy ilçesinde görev yapan kamu çalışanları oluşturmaktadır. 


\subsection{Veri Toplama araçları ve teknikleri}

Rastlantısal örneklem metodunun seçildiği çalışma için anket yöntemi kullanılmıştır. Araştırmada anket metodu ile veri toplama yolu izlenmiştir. Yaşamda anlam varlığını ölçmek içi Steger, Frazier, Oishi ve Kaler (2006) tarafından geliştirilen ölçek kullanılmıştır. Örgütsel Psikolojik Sermaye algısını ölçmek amacıyla Luthans ve diğerleri (2007) tarafından geliştirilen Psikolojik Sermaye Ölçeği kullanılmıştır. Ölçek 24 maddeden ve 4 alt boyuttan (öz yeterlilik, iyimserlik, umut, dayanıklılık) oluşmuştur.

\subsection{Verilerin analizi, bulgular ve tartışma} sunulmuştur.

Araştırmaya katılanların demografik özellikleri, katılımcı sayıları ve yüzdeleri ile aşağıda

Tablo 1: Araştırmaya Katılanların Cinsiyete Göre Dağılımları

\begin{tabular}{|l|c|c|}
\hline Cinsiyet & Frekans & Yüzde (\%) \\
\hline Erkek & 57 & 52,3 \\
\hline Kadın & 52 & 47,7 \\
\hline Toplam & 109 & 100,0 \\
\hline
\end{tabular}

Tablo 1'de görüldüğ̈̈ üzere araştırmaya katılanların \% 52,3'ü erkek, \% 47’7 si kadın katılımcılardan oluşmaktadır.

Tablo 2:Araştırmaya Katılanların Yaşa Göre Dağılımları

\begin{tabular}{|l|c|c|}
\hline Yaş & Frekans & Yüzde (\%) \\
\hline $18-25$ & 2 & 1,8 \\
\hline $26-30$ & 10 & 9,2 \\
\hline $31-35$ & 16 & 18,3 \\
\hline $36-40$ & 18 & 14,7 \\
\hline 40 üstü & 43 & 39,4 \\
\hline Toplam & 109 & 100,0 \\
\hline
\end{tabular}

Tablo 2'de görüldüğü üzere araştırmaya katılanların \% 1,8'i 18-25 yaş aralığında \% 9,2'si 2630 yaş aralığında, \% 18,3'ü 31-35 yaş aralığında, \% 14,7'si 36-40 yaş aralığında ve \% 29,4'ü 40 yaş üstü grubundan oluşmaktadır.

Tablo 3:Araştırmaya Katılanların Eğitimine Göre Dağılımları

\begin{tabular}{|l|c|c|}
\hline Ĕgitim & Frekans & Yüzde (\%) \\
\hline Ön Lisans & 28 & 25,7 \\
\hline Lisans & 57 & 52,3 \\
\hline Yüksek Lisans ve Üstü & 24 & 22 \\
\hline Toplam & 109 & 100,0 \\
\hline
\end{tabular}

Tablo 3'de görüldüğü üzere araştırmaya katılanların \% 25,7'ü ön lisans, \% 52,3’ü lisans ve \% 22'si yüksek lisans ve üstü eğitim almışlarıdır. 
Faktör analizinde bağımlı ve bağımsız değişkenler arasında korelasyon ilişkisinin olup olmadığı sorgulamaktadır. Değişkenler arasındaki korelasyon ilişkisi azaldıkça faktör analizi ile ortaya çıkan sonuçlara olan güven de azalma göstermektedir. Araştırmamızın değiş̧kenleri ayrı ayrı faktör analizine tabi tutulmuştur. $\mathrm{P}($ sign) değeri 0,05 'in altında olduğundan Barlett testinin sonucu anlamlıdır. $\mathrm{Bu}$ araştırmada, KMO genel kabul gören değer olan 0,5 'in üzerinde çıkmış olup araştırmanın örneklem büyüklüğün yeterli sevide olduğunu göstermektedir. Yaşamın anlamı değişkeninin soruları temel bileşenler yöntemi ve Varimax döndürme yöntemi kullanarak sorular analize tabi tutulmuştur. Örneklem yeterlik ölçüsü 0,5 'nin altında kalan, faktör altında tek kalan, birbirlerine yakın faktör ağırlıkları olan sorular analizden çıkarılarak yapılan faktör analizinde öz değerleri 1 ve üzerinde olan iki faktör elde edilmiştir (Özdemir A. , 2013:314). Tablo 4'da Hayatın Anlamı değişkeni için güvenilirlik analizleri yapıldığında her iki faktörün 0,70 güvenilirlik düzeyinin üstünde olduğu tespit edilmiştir. Toplam açıklanan varyans \% 64,384 olarak bulunmuştur.

Tablo 4: Yaşamın Anlamı Faktör Analizi Sonuçları

\begin{tabular}{|c|c|c|c|c|}
\hline $\begin{array}{l}\text { Faktörün } \\
\text { Adı }\end{array}$ & Soru İfadesi & $\begin{array}{l}\text { Faktör } \\
\text { Ăgırlıkları }\end{array}$ & $\begin{array}{l}\text { Faktörün } \\
\text { Açıklayıcılığı }\end{array}$ & Güvenilirlik \\
\hline \multirow{4}{*}{ 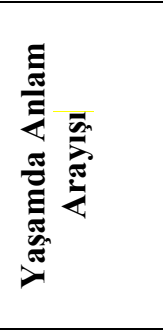 } & $\begin{array}{l}\text { Hayatımı anlamlı hissettirecek bir şey } \\
\text { ararım }\end{array}$ & 0,793 & \multirow{4}{*}{38,811} & \multirow{4}{*}{0,844} \\
\hline & $\begin{array}{llll}\begin{array}{l}\text { Daima } \\
\text { çalışırım }\end{array} & \text { hayatımın } & \text { amacını } & \text { bulmaya } \\
\end{array}$ & 0,769 & & \\
\hline & $\begin{array}{l}\text { Daima hayatımı önemli hissettirecek bir şey } \\
\text { arıyorum }\end{array}$ & 0,835 & & \\
\hline & $\begin{array}{l}\text { Hayatım için bir amaç ya da bir görev } \\
\text { ararım }\end{array}$ & 0,876 & & \\
\hline \multirow{3}{*}{ 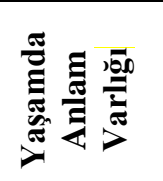 } & Hayatımın anlamının bilincindeyim. & 0,821 & \multirow{3}{*}{26,041} & \multirow{3}{*}{0,729} \\
\hline & $\begin{array}{l}\text { Hayatımı neyin anlamlı kıldığını iyi } \\
\text { biliyorum }\end{array}$ & 0,872 & & \\
\hline & Tatmin edici bir yaşam amacı keşfettim & 0,560 & & \\
\hline \multirow{2}{*}{\multicolumn{4}{|c|}{\begin{tabular}{r|c} 
Toplam & 64,853 \\
Kaiser-Meyer-Olkin Ölccek Geçerliliği
\end{tabular}}} & \\
\hline & & & & 0,694 \\
\hline \multicolumn{4}{|c|}{$p$ değeri } & 0,000 \\
\hline
\end{tabular}

Yine, örgütsel psikolojik sermaye soru grubu için yapılan faktör analizinde bu soru grubunun dört boyuttan oluştuğu ve açılama oranı \% 55,841 olduğu ortaya çıkmıştır $(\mathrm{KMO}=0,811, \mathrm{p}=0,000)$. Elde edilen dört boyutun güvenilirlik analizi sonucunda Cronbach Alfa değerinin 0,834 olması bu dört faktörün iç tutarlığının yüksek olduğunu göstermektedir (Durmuş, Yurtkoru, \& Çinko, 2011:89).

Araştırma sonucunda yapılan analiz neticesinde bağımlı ve bağımsız değişkenlere ait korelasyon katsayı değerleri tablo 5'da verilmektedir. Korelasyon katsayı değerleri bütün bağımsız ve bağımlı değişkenler arasında birebir ve anlamlı bir ilişkinin olduğunu dair güçlü işaret etmektedir. İlgili değişkenlere ait çıkarılan ortalama varyans değerinin karekökü alındığında korelasyon katsayı değerlerinin tamamı AVE değerinin karekökünden küçük olarak çıktığı görülmektedir. Korelasyon tablosundan açıkça görüldüğü gibi Yaşamın Anlamı değişkenin alt boyutunu olan "Yaşamda Anlam Varlığı" ile "Örgütsel Psikolojik Sermaye" değişkenin alt boyutları arasında pozitif yönde güçlü ilişki varllğı tespit edilmiştir. 
Tablo 5:Değişkenlerin Korelasyon Katsayı Değerleri

\begin{tabular}{|l|c|c|c|c|c|}
\hline Değişkenler & $\mathbf{1}$ & $\mathbf{2}$ & $\mathbf{3}$ & $\mathbf{4}$ & $\mathbf{5}$ \\
\hline İyimserlik & $\mathbf{1}$ & & & & \\
\hline Psikolojik Dayanıklık &, $487^{* *}$ & $\mathbf{1}$ & & & \\
\hline Umut &, $551^{* *}$ &, $638^{* *}$ & $\mathbf{1}$ & & \\
\hline Öz Yeterlik &, $502^{* *}$ &, $688^{* *}$ &, $678^{* *}$ & $\mathbf{1}$ & \\
\hline Anlam Varlığ &, $519^{* *}$ &, $379^{* *}$ &, $496^{* *}$ &, $452^{* *}$ & $\mathbf{1}$ \\
\hline
\end{tabular}

Kuramsal çerçevede genelinde ileri sürülen hipotezlerin testi için regresyon analizi yapılmıştır. Hayatın Anlam Varlığı ile Örgütsel Psikolojik Sermaye boyutları arasında yapılan ANOVA testi sonucunda elde edilen veriler tablo 6'da görülmektedir.

Tablo 6: Yaşamın anlam varlığı ile örgütsel psikolojik sermaye arası regresyon analizi

\begin{tabular}{|l|l|l|l|}
\hline Bağımsız Değişkenler & Beta Katsayıst & t Dĕ̆eri & p Değeri \\
\hline İimserlik &, 584 & 6,283 &, 000 \\
\hline Psikolojik Dayanıklılık &, 379 & 4,230 &, 000 \\
\hline Öz yeterlik &, 326 & 5,235 &, 000 \\
\hline Umut &, 433 & 5,911 & 000 \\
\hline
\end{tabular}

Tablo 6'da elde edilen verilere göre;

Korelasyon ve regresyon tablosunda açıç̧a görüleceği üzere ilk dört hipotezimizde ifade edilen pozitif yöndeki ilişkinin doğruluğu kanıtlanmaktadır.

H1: Yaşamda anlam varlığı ile örgütsel psikolojik sermayenin öz yeterlilik boyutu arasında pozitif yönde ilişki vardır" $\left(\mathrm{R}^{2}=, 204\right.$, ayarlanmış $\mathrm{R}^{2}=, 196$, p değeri=,000) Desteklenmiștir.

H2: Yaşamda anlam varlığı ile algısı ile örgütsel psikolojik sermayenin iyimserlik boyutu arasında pozitif yönde ilişki vardır. $\left(\mathrm{R}^{2}=, 296\right.$, ayarlanmış $\mathrm{R}^{2}=, 263$, p değeri=,000) Desteklenmiștir.

H3: Yaşamda anlam varlığı ile örgütsel psikolojik sermayenin umut boyutu arasında pozitif yönde ilişki vardır. $\left(\mathrm{R}^{2}=, 246\right.$, ayarlanmış $\mathrm{R}^{2}=, 239$, p değeri=,000). Desteklenmiștir.

H4: Yaşamda anlam varlığı ile örgütsel psikolojik sermayenin psikolojik dayanıklılık boyutu arasında pozitif yönde ilişki vardır. $\left(\mathrm{R}^{2}=, 143\right.$, ayarlanmış $\mathrm{R}^{2}=, 135$, p değeri $\left.=, 000\right)$. Desteklenmiștir.

\section{Tartışma}

Araştırmamız sonucunda yaşamda anlam varlı̆̆g ile örgütsel psikolojik sermayenin "öz yeterlik" boyutu arasında pozitif yönde ilişki tespit edilmiştir. "Yaşamda anlam varlığı", bireyin kendi yaşamını veya varlığını önemli, anlamlı ve değerli görme derecesini temsil etmektedir. Bu bağlamda yaşamını anlamlı bulan bireylerin zorlu işleri başarmak veya amaçlarına ulaşmak için gerekli enerjiyi ortaya koyacaklarını ve kendi yeteneklerine güveneceklerini söylemek mümkündür. Bu sonuç Aydıner (2011) çalışması ile kısmi benzerlik göstermektedir. Aydıner (2011) çalışmasında yaşam amacı ile genel özyeterlik arasında pozitif ilişki tespit etmiştir.

Yapılan analiz neticesinde yaşamda anlam varlı̆̆ ile örgütsel psikolojik sermayenin "iyimserlik" boyutu arasında pozitif yönde ilişki tespit edilmiştir. İyimserlik boyutu psikolojik sermayenin kalbi sayılmaktadır (Luthans,2002). Araştırmanın bulguları ışığında yaşamını anlamlı bulan bireylerin şimdi ve gelecekte başarılı olacaklarına dair iyimser tavır sergileyebileceklerini söylemek mümkündür. Nitekim Demir ve Murat (2017) iyimserliğin, yaşamın anlamını yordadığını tespit etmiştir. 
Yine, araştırmamız sonucunda yaşamda anlam varlığı ile örgütsel psikolojik sermayenin "umut" boyutu arasında pozitif yönde ilişki olduğu tespit edilmiştir. Umut, bireyin amaca giden yolda umudunu kaybetmemesini temsil etmektedir. Araştırmanın bulgusu 1şı̆̆ında yaşamında anlam bulan bireylerin umutlarını kaybetme ihtimalinin çok daha düşük olacağını söylemek mümkündür. Nitekim Şahin ve diğerleri (2012) çalışmalarında yaşamda anlam varlığı ile umut arasında pozitif ilişki tespit etmişlerdir.

Son hipotezde ileri sürülen ve araştırma sonucu ile ede edilen verilere göre yaşamda anlam varlığı ile örgütsel psikolojik sermayenin psikolojik dayanıklılık boyutu arasında pozitif yönde ilişki olduğu tespitine varılmıştır. Psikolojik dayanıklılık zorluklar karşısında ayakta kalmaktır demektir. Bu bağlamda yaşamında anlam bulan bireylerin zorluklar karşısında daha dayanıklı olabileceğini söylemek mümkündür. Nitekim Nietzsche "yaşamak için bir nedeni olan her nasıla katlanır" demiştir. Keza anlam kavramının en önemli kuramcısı Viktor E. Frankl İkinci Dünya Savaşında Yahudi toplama kamplarında hayatta kalmasını anlam ile açıklamıştır. Wong ve Wong (2012) yaşamda anlam varlığının psikolojik dayanıklılık ile pozitif ilişkisi içinde olduğunu; Demirbaş (2010) yaşamda anlam varlığının psikolojik dayanıklılığın "toparlanma için gerekli bireysel güçlü yönler "ve "bireyin kendine yönelik olumlu bakış açısı" boyutları arasında pozitif ilişki tespit etmiştir.

\section{Sonuç ve Öneriler}

Pozitif psikolojinin yönetim alanında yansıması pozitif örgütsel davranış olarak gerçekleşmiştir. Örgütsel psikolojik sermaye, pozitif örgütsel davranışın çatısı altında kabul edilmektedir. Örgütsel psikolojik sermaye günümüzde gerek kâr elde eden gerekse kâr amacı gütmeden hizmet üreten organizasyonlar için hayati öneme sahip dâhili varlık durumundadır. Bir organizasyonun gücü onun nasıl yönetildiği ve ürettiği çıktılar ile doğrudan alakalıdır. Sektörünüzde daha az zamanda daha az maliyet ile daha kaliteli ürün/hizmet üretiyorsanız o sektörün lideri olmamanız kaçınılmaz olmaktadır. Psikolojik sermeye kavramı tam da burada devreye girmektedir. Eğer çalışan insan kaynaklarınız organizasyonun misyonunu ve vizyonunu gerçekleştirecek psikolojik sermayeye sahip ise başarı kaçınılmaz olmaktadır. O halde insan kaynakları seçiminde örgütsel psikolojik sermeyenin alt bileşenleri olan iyimserlik, psikolojik dayanıklılık, umut ve öz yeterlik kişilik özelliklerine dikkat edilmelidir.

$\mathrm{Bu}$ çalışmada ele aldığımız diğer değişkenimiz olan yaşamın anlamı yine örgütlerin insan kaynakları faktörünü doğrudan ilgilendirmektedir. Yaşamının anlamı hakkında arayış içinde olan veya anlamsızlık yaşayan birey/çalışan doğru sonuçlar üretemeyebilir. Çünkü yaşamda anlam varlığı her şeyden önce bireyin çabalarını bir amaca yöneltmesini ifade etmektedir. Ayrıca yaşamda anlam zenginliği, amaç ile birlikte bireyde çaba da oluşturduğu unutulmamalıdır.

Hayatını amaçsız bir şekilde sürdüren bir birey insanlık için değer üretemeyeceği gibi amaçsız bir örgüt de o kurumdan beklenen doğru sonuçları üretemeyecektir. Ülkemizde, günümüz iş dünyasında her gün birçok şirket faaliyete başlamakta ve yine birçoğu faaliyetini sonlandırmak zorunda kalmaktadır. Söz konusu bu firmaların/örgütlerin faaliyetlerine son vermelerinin ana nedenin sağlıklı bir örgütsel sermayeye sahip olunmadıkları ve hayatının anlamını tam olarak kavramış bireylerin yeterince olmadığı kanaati hâkim unsur olarak karşımıza çıktığı düşünülmektedir.

Özellikle son yıllarda personel güçlendirme kavramı ile karşımıza çıkan çalışanın daha fazla inisiyatif ve sorumluk alması olgusu örgütler için göz ardı edilmemeş gereken bir süreç halini almıştır. Müşteri odaklılık bağlamında, müşteri isteğinin en kısa sürede ve kalite yerine getirilmesi için en uç birimdeki çakışanımızın gerekli bilgi birikimi ve donanıma sahip olması gerekir. İşte hayatın anlamını bulabilen bir birey örgütün pozitif çıktı üretmesinde çok güçlü katkı sağlayacaktır.

$\mathrm{Bu}$ araştırma, örgütsel davranış bilimlerinde, yaşamda anlam varlığı ile örgütsel psikolojik sermeye bileşenlerinin birlikte incelenmesinin önemine vurgu yapılması ve bu konuda çalışma yapacak 
araştırmacılara katkı sağlanması amacıyla yapılmıştır. Böyle bir araştırmanın Türkiye'de ilk defa yapılıyor olması ayrıca önem arz etmektedir.

\section{KAYNAKÇA}

Adler, A. (1985). "Yaşamın anlamı ve amacı". Say Yayınları,12.Baskı, İstanbul

Avey, J. B, Luthans, F. ve Youssef, C.M. (2010). “The Additive Value Of Positive Psychological Capital In Predicting Work Attitudes And Behaviors”. Journal Of Management,36(2), ss.1-42

Avey, J., Luthans, F. \& Jensen, F. (2009).” Psychological capital: a positive resource for combating employee stress and turnover". Human Resource Management,48(5), pp.677-693

Avey, J., Wernsing, T.\& Luthans, F. (2008)." Can positive employees help positive organizational change? impact of psychological capital and emotions on relavant attitudes and behaviors". The Journal of applied behavioral studies,44(1), pp.48-60

Aydıner, B.B. (2011). "Üniversite öğrencilerinin yaşam amaçlarının alt boyutlarının genel öz-yeterlik yaşam doyumu ve çeşitli değişkenlere göre incelenmesi”. Sakarya Üniversitesi Eğitim Bilimleri Enstitüsü, Yüksek Lisans Tezi, Sakarya

Bandura, A. (1994). Self-efficacy. In V. S. Ramachaudran (Ed.), Encyclopedia of human behavior (Vol. 4, pp. 71-81). New York: Academic Press. (Reprinted in H. Friedman [Ed.], Encyclopedia of mental health. San Diego: Academic Press, 1998).

Bannink, F. (2017).”201 Pozitif psikoloji uygulaması”. Üsküdar Üniversitesi Yayınları,1.Baskı, İstanbul

Baumeister, R.F., Vohs, K.D., Aeker, J.L. \& Garbinsky, E.N. (2013).” Some key differences between a happy life and a meaningful life". The Journal Of Positive Psychologhy,8(6), pp.505-516

Baumeister,R.F. and Vohs, K.D.(2005)."The pursuit of meaningfulness in life".https://jwdezeeuw.files.wordpress.com/2013/03/baumeister-r-f-en-k-d-vohs-1999-thepursuit-of-meaningfulness-in-life.pdf

Cantore, S. ve Passmore, J. (2012). "Top Business Psychologhy Models: 50 Transforming Ideas For Leaders, Consultants And Coaches".by Kogan Page Limited, USA

Couto, D. L.(2002).”How resilience works". Harvard Business Review,80(5), pp.46-55

Demir, R.ve Murat, M. (2017). "Öğretmen adaylarının mutluluk, iyimserlik, yaşam anlamı ve yaşam doyumlarının incelenmesi”. OPUS Uluslarası Toplum Araştırmaları Dergisi,7(13), ss.346-378

Demirbaş, N. (2010). "Yaşamda anlam ve yılmazlık". Hacettepe Üniversitesi Sosyal Bilimler Enstitüsü, Yüksek Lisans Tezi, Ankara

Doğan, T., Sapmaz, F., Tel, F.D., Sapmaz, S., \& Temizel, S. (2012).” Meaning in life and subjective well-being among Turkish University Students”. Procedia-Social And Behavioral Sciences, 55, pp.612-617

Durmuş, B., Yurtkoru, S., \& Çinko, M. (2011). “Sosyal bilimlerde SPPS'le veri analizi”. Beta Yayınları, İstanbul

Eley, D.S., Cloninger, R., Walters, L., Lawrence, C. (2013).” The relationship between resilience and personality traits in doctors: Implications for enhancing well being".PEERJ,216,pp.1-16 
Feldman, D.B.and Snyder, C.R. (2005).” Hope and the meaningful life: Theoretical and empirical associations between goal-directed thinking and life meaning". Journal Of Social And Clinical Ppsychology, Vol. 24, No. 3, pp. 401-42

Flammer, A.(2001)."Self-Efficacy".International Encyclopedia Of The Social \& Behavioral Sciences, December, pp.1-5

Frankl, V.E. (2012).” İnsanın anlam arayışı”. Okuyan Us Yayın Eğitim, VI. Baskı, İstanbul

Froman, L. (2010). "Positive Psychologhy In The Work Place”. Springer,17(2), pp.59-69

Işık, Ş. (2016). “Türkiye'de kendini toparlama gücü konusunda yapılmış araştırmaların incelenmesi”. PDR,6 (45), ss.65-76

Luthans, F., Avolio, B.J., Avey, J. B. \& Norman, S. M. (2007). "Positive Psychological Capital: Measurement and Relationship with Performance and Satisfaction”. Personnel Psychology. 60, pp. 541-572.

Luthans, F., Luthans, K.W., Luthans, B.C. (2004). "Positive Psycological Capital: Beyond Human And Social Capital". Published In Business Horizons,47(1), s.45-50

Luthans, F.(2002)."Positive organizational behavior: Developing and managing psychological strengts".Academy Of Management Executive,16(1),ss.57-72

Maddi, S. (1967).” The existential neurosis". Journal Of Abnornal Psychology, 72, pp.311-325.

Maddi, S.(2006)."Hardiness: The courage to grow from stresses".The Journal Of Positive Psychologhy,1(3),pp.160-168

Martela, F.and Steger, M.F. (2016).” The three meaning of meaning of life: Distinguishing coherence, purpose and significance".The Journal Of Positive Psychologhy,11(5),pp.531-545

Ocak, M ve Güler, M. (2016).” Psikolojik sermayenin tükenmişlik üzerine etkisi: Görgül bir araştırma".4.Örgütsel davranış kongresi, ss.118

Özdemir, A. (2013).” Yönetim biliminde ileri araştırma yöntemleri ve uygulamalar”. Beta Yayınları, İstanbul

Özerden, S.T. (2010). “Turizm işletmelerinde çalışan bireylerin öz yeterlilik algılarının psikolojik şiddet (mobbing) olgusu üzerindeki etkisi: K.K.T.C'de bir uygulama”.Akdeniz Üniversitesi Sosyal Bilimler Enstitüsü, Yüksek Lisans Tezi, Antalya

Pyszcynski, T., Solomon, S., \& Greenberg, J. (2015).” Thirty years of terror management theory”. Elsevier, pp.1-73

Seligman, M.E. P. (2002).” Authentic happiness". Free Press, New York

Seligman, M.E. P. and Csikszentmihalyi, M. (2000).” Positive Psychologhy, An introduction". American Psychologist,55 (1), pp.5-14

Seligman, M. E.(2006)."Learned Optimism, How to change your mind and your life".First Vintage Books Edition, USA

Snyder, C. R., Rand, K. L., \& Sigmon, D. R. (2002). "Hope theory: A member of the positive psychology family”. In C. R. Snyder \& S. J. Lopez (Eds.), Handbook of positive psychology (pp. 257-276). New York, NY, US: Oxford University Press. 
Steger, M.F., Frazier, P., Oishi, S., \& Kaler, M. (2006).” The meaning in life questionnaire: Assessing the presence of and search for meaning in life". Journal Of Counseling Psychologhy,53(1), pp.80-93

Synder, C.R., Ilardi, S.S., Cheavens, J., Michael, S.T., Yamhure, L., \& Sympson, S. (2000).” The role of hope in cognitive -behavior therapies". Cognitive Therapy And Research,24, pp.747-776

Şahin, M., Aydın, B., Sarı, S.V., Kaya, S. \& Pala, H. (2012)”. Öznel iyi oluşu açıklamada umut ve yaşamda anlamın rolü”. Kastamonu Eğitim Dergisi,20(3), ss.827-836

Taş, İ. (2015). "Yaşam anlamı, Pozitif Psikoloji”. Bölüm 10, Nobel Akademik Yayıncılık, Ankara

Triplett, K. N., Tedeschi, R. G., Cann, A., Calhoun, L. G., and Reeve, C. L. (2012). "Posttraumatic growth, meaning in life, and life satisfaction in response to trauma. Psychological Trauma: Theory, Research, Practice, and Policy". 4(4), pp.400-410.

Windle, G.(2010).”What is resilience? A review and concept analysis".Cambridge University Press,21 December, pp.1-18

Wong, P.T.P and Wong, L.C. J. (2012)." A Meaning-centered approach to building youth resilience". http://www.drpaulwong.com/documents/HQM2-chapter27.pdf

Yalom, I.D. (1980).” Existential psychotherapy”. Basic Books, New York

Yaşin, T. (2016). "Kişilik özellikleri ve psikolojik sermayenin psikolojik iyi oluş, akış deneyimi, iş tatmini ve çalışan performansına etkisi”. Başkent Üniversitesi, İşletme Anabilim dalı, Doktora tezi

Zika and Chambrelin, K. (1992)." On the relation between meaning in life and psychological wellbeing". British Journal Of Psychology, 83 (1), pp.133-146. 